\title{
THE NECESSITY FOR THE IMPLEMENTATION OF A GLOBAL ENVIRONMENTAL POLICY FOR THE NEEDS AND CONDITIONS AND LOCAL COMMUNITIES. A COMPARATIVESTUDY
}

\author{
Magdalena Sitek ${ }^{1}$, BronisŁaw SiteK ${ }^{2}$ \\ Alcide de Gasperi University of Euroregional Economy in Jozefów, SWPS University of Social Sciences \\ and Humanities in Warsaw (Poland)
}

\begin{abstract}
Dynamic economic development, especially of highly industrialised regions, is a real threat to the local community through the too extensive exploitation of the natural environment. In the field of environmental protection, a global policy of sustainable development is applied, of which numerous conventions and international agreements are the evidence. From a regional point of view, however, the policy created by the regional authorities is of greater importance. This claim is also a research hypothesis of this research. Hence, the subject of this study will be the analysis of environmental protection policies carried out by the authorities of two partner municipalities, Józefów in Poland and Bitetto in Italy. The aim of the study is to assess the effectiveness of the activities of the local authorities of two partner municipalities in terms of local environmental protection, and to show that environmental policies should take into account in global and national approaches, but they should take their real shape based on local conditions and needs. The result of the work will be the conclusions on the effectiveness of local environmental protection policy. The study will use the method of analysing local environmental protection strategy and statistical data analysis, and an analysis of Polish and Italian law. KEY WORDS: environmental protection, tasks of local authorities, environmental exploitation.
\end{abstract}

JEL CODES: Q 58.

DOI: http://dx.doi.org/10.15181/rfds.v34i2.2255

\section{Introduction}

Visible climate changes, such as global warming or the melting of Antarctica, and consequently rising sea and ocean levels, sparked a global discussion on the need to protect the natural environment. Numerous acts in international law of a global or regional nature are the result of this discussion. There are usually provisions classified as soft law, and therefore absolutely not binding on the governments of individual countries. Within the framework of the United Nations, and later the European Union, numerous institutions and organisations have been established to deal with the protection of the environment in a professional and scientific way. Environmental protection is also one of the main goals of global policy, as well as of highly developed and developing countries.

The main research problem is to examine the impact of environmental degradation on the tasks of the regional authorities, especially local government, in terms of stopping local processes leading to the destruction of the environment. The subject of the research is the analysis of possible actions by regional autho-

Magdalena Sitek - dr. hab., rector of Alcide De Gasperi University of Euroregional Economy in Jozefów (Poland)

Scientific interests: law, environmental law, EU law, human rights

E-mail:ms@wsge.edu.pl

2 Bronisław Sitek - prof. dr. hab., secretary of the Scientific Excellence Council, professor at SWPS University of Social Sciences and Humanities in Warsaw

Scientific interests: law, Roman law

E-mail: bronislaw.sitek@gmail.com 
rities in terms of methods of effective environmental protection. The development of global environmental protection policy has not brought the expected results after several decades of operation. The amount of municipal and industrial waste is not decreasing. Industrial waste from mining, energy, and above all, metallurgy, is the biggest problem here. This type of waste accounts for up to $90 \%$ of all waste. This state of affairs is not changing, despite the policy of sorting and reusing waste in order to generate energy (DuczkowskaKądziel, Duda, 2014: 172-187).

The aim of the study is to investigate the impact of global (international) environmental policy on environmental regional policy. The aim is to find ways to increase the efficiency of environmental policy. The further regionalisation of this policy seems to be an appropriate solution, which would allow it to be adapted to the needs and requirements of a specific place. For this reason, the study will be limited to an analysis of the regional environmental protection policies of two municipalities, one in Poland and the other in Italy, which have been cooperating for many years. This analysis will be limited to legal texts, the development strategies of these communes, and other local normative documents.

The main research tasks include the analysis of international law and normative provisions and local documents. The work is comparative. The work uses the legal and dogmatic method, thanks to which the analysis of texts of international and regional law was carried out. In addition, the descriptive and comparative methods were used to characterise the compared places, especially their environmental values.

\section{Global or regional environmental policy}

\subsection{United Nations law}

Environmental protection is one of the basic goals of world politics. For this purpose, numerous scientific conferences and environmental organisations are convened. However, the most important are international meetings of heads of state organised by the United Nations. The idea to convene a global conference with the participation of heads of state arose on 20 December 1988 at the UN General Assembly. The resolution adopted at that time (43/196) referred to the Stockholm Conference of 1972 (Ignatowski, 1994: 134-135), during which the Declaration of the United Nations Conference on the Natural Environment was adopted. In Principle 16 of the declaration, attention was drawn to the need to introduce regional solutions. However, in our opinion, the lack of proper protection of the natural environment in these regions is not the result of demographic imbalance, as is suggested in this document, but of the former colonial policy conducted for several centuries by modern European countries.

The first, the so-called Earth Summit, was held in 1992 in Rio de Janeiro. The provisions adopted there, including Agenda 21, containing an action plan for sustainable development, were supposed to be global in nature (Selman, 1998: 533-553). According to the authors of this document, sustainable development should be correlated with economic development and human rights. Agenda 21 points out, inter alia, that it is necessary to diversify technological and economic support for less developed countries and regions (2.16 c). An emphasis was also placed on the development of international and regional cooperation in the field of environmental protection (2.38) (Sitarz, 1993).

However, what is important in Agenda 21 is the recognition of the importance of local communities in the process of implementing the principles of sustainable development. The appropriate competences of the local community in this regard should be reflected in national strategies (2.37). The role of local communities in the process of implementing principles of sustainable development has also been linked to activities aimed at eradicating poverty. Combatting poverty is an essential element of sustainable development (3.2).

At the next Earth Summit in Johannesburg in 2002, heads of state focused mainly on developing a strategy for implementing the principles of sustainable development. Local Action Moves the World was established. The task of this institution is to exchange information and experiences between regions. In this way, a database for information exchange between local communities and representatives of various state authorities was established. In Poland, the assumptions adopted in Agenda 21 since 1994 are implemented at the 
level of municipalities and powiats. The United Nations Development Programme plays a special role here (Brugman, 2014: 40-48). Current activities by the United Nations in the field of environmental protection are based on the resolution adopted by the General Assembly on 25 September 2015 entitled 'Transforming our World: The 2030 Agenda for Sustainable Development'. In this document, the states-parties undertook to support and strengthen the participation of local communities in improving the management of water resources and improving sanitation (6b).

The effect of UN regionalisation in the field of environmental protection is the creation of four regional departments within the UN Environmental Programme. Each of these departments has another three offices, located in different parts of the region (UN Environment Programme, Structure). The basic assumption of this programme is that the law is the most important instrument for implementing sustainable development, and thus environmental protection. It was pointed out that without appropriate legal norms and clearly defined legal principles from which specific obligations of public authorities would arise, environmental management will become unpredictable in its effects (Ivanova, 2020: 307-324; UN, Environmental Rule of Law). The report prepared by the UN Environmental Programme indicated the ineffectiveness of the law (UN, Environmental Rule of Law). In our opinion, the low effectiveness of the environmental protection law created with the participation of the United Nations is due to the fact that an extremely important global normative solution is then not properly adjusted to the capabilities and needs of individual regions.

\subsection{European Union law}

The European Union undoubtedly has the most developed environmental protection policy of a regional nature. Already in the 1980 s, various legislative initiatives were undertaken within the framework of the European Economic Community, or new institutions were created to protect the environment. The basic act on which the Community, or, since 1992, the European Union, environmental policy has been built are the action programmes of the European Communities for environmental protection (Ciechanowicz-Maclean, 2009: 32). On behalf of the European Union, the European Environment Agency is the body responsible for the implementation of environmental policy. One of the agency's tasks is to aggregate data on local environmental threats. On this basis, it is possible to adapt European Union actions to the needs and capabilities of a given region (Sitek, 2014: 231-247; Kenig-Witkowska, 2012: 20; Antczak, 2010: 65).

The possibility of implementing local legal regulations regarding environmental protection results from Article 114, Paragraphs 4 and 5, of the Treaty on the Functioning of the European Union. The unification of the legal system in the EU is dictated primarily by the creation of a common market (Article 26 of the TFEU). However, if necessary, a member state may maintain old or introduce new national provisions for environmental reasons. The confirmation of the partial regionalisation of EU environmental policy is also found in Article 191, Paragraph 3. This provision stipulates that the diversity of environmental conditions in the various regions should be considered when designing the union's environmental policy (Peña Rodriguez, 2020: 35).

\subsection{Polish law}

Pursuant to Article 5 of the Constitution of the Republic of Poland, the Republic of Poland is obliged to ensure environmental protection, guided by the principle of sustainable development. Hence, due to the need for protection of the environment, restrictions on the exercise of constitutional rights and freedoms may be introduced (Article 31, Paragraph 3 of the Constitution of the Republic of Poland). Public authorities are obliged to prevent negative effects of environmental degradation on the health of citizens (Article 68, Paragraph 4). This means that the public authority is obliged to formulate and ensure the implementation of an ecological safety policy (Olejarczyk, 2016: 119-140).

This is a constitutional task carried out by state organs through laws and various institutions. The most important legislation is the Act of 27 April 2001 on environmental protection (Journal of Laws of 2020, Item 
1219). There are numerous examples of the centralisation or regionalisation of environmental policy in this act. In Article 14, Section 2, the legislator decided that environmental protection policy should be implemented through, inter alia, municipal environmental protection programmes. Pursuant to Article 17, Section 1, such a programme should be prepared by the executive body of the municipalities. According to Article 7, Section 1, Point 1 of the Act of 8 March 1990 on local government (Journal of Laws of 2020, Item 713), the tasks of the commune in Poland include, inter alia, the protection of the environment and nature. A particular concern of the commune should be financing activities in the field of waste management, protection of the earth's surface, supporting the production of local renewable energy sources and other projects related to environmental protection (Alexandrowicz, 1994: 164-165; Rakoczy, 2009: 67).

\subsection{Italian law}

According to Article 117, Point s of the Constitution of the Italian Republic, the state has exclusive legislative powers, inter alia, in the field of protection of the environment, the ecosystem and the cultural heritage. This formulation is undoubtedly a manifestation of the very strong centralisation by the state of the possibility of creating nationwide law in the field of environmental protection. It is therefore a kind of state monopoly. At the same time, the obligations resulting from international law and the tasks assigned by law to regions and municipalities are respected.

The decree (with the legal power of an act) of 3 April 2006, No 152, the environmental protection law (Italian Official Gazette, n88 of 14 April 2006), contains a number of quite detailed solutions in the field of environmental protection, on the basis of which municipalities will receive a number of rights and obligations. And therefore, in Article 205, the municipalities are responsible for the collection of municipal waste. However, it cannot be a simple aggregation of waste, but must also be sorted in terms of its recyclability or use for energy production. Based on Article 212, the municipality makes an entry on the central list of entities dealing with environmental administration. The municipality is also the statutory body obliged to provide public information about the state of the environment in its area.

An analysis of the tasks of Italian municipalities in terms of environmental protection is possible on the basis of the Decree-Law of 18 August 2000, n4 267, the uniform text of the law on the organisation of local government units (Italian Official Gazette, No 227 of 28 September 2000, Supplement No 162). The article, Section 3 of this Act, points out that associations are of fundamental importance to the protection of the environment in the municipalities. It is the association which most often takes action to eliminate environmental damage. The task of the municipality is to support such associations.

\section{Environmental protection from the perspective of local law based on the example} of two municipalities

The analysis of global legal provisions created by the United Nations or the European Union shows that effective protection of the natural environment requires taking into account the geographical, regional or local context. Environmental protection policy should be adjusted to the needs and possibilities of the local community. Responsibility for the creation and implementation of the local community rests with the regional authorities, but above all with the local authorities of the municipality. We should also consider the legal conditions for economic activity of regions or local governments in connection with the protection of the natural environment (Ciekanowski, Ulijasz, 2015: 83).

It is therefore necessary to show the legal basis for the implementation of such a policy, in other words, the competence of the municipal authorities. It is also important to analyse local strategies: this means the action plans of municipal authorities, which also bind the local community. The purpose of this activity is to determine the effectiveness of regional environmental protection policy. This task will be performed using the comparative method. Thanks to this method, the local policies of two municipality will be discussed and compared, Józefów in Poland and Bitetto in the south of Italy. The selection of these cities is not accidental. 
Since 2008, these cities have been connected by a cooperation agreement, which includes, inter alia, the development of both cities (Uchwała Nr 199/IV/04 Rady Miasta Józefowa of 27 May 2004).

\subsection{Local environmental protection policy in the Józefów municipality}

The population of Józefów is approximately 21,000 people. It is located near the border with Warsaw. The town received municipal rights in 1962. Józefów is therefore not a town with long historical traditions, but it has extraordinary climatic and environmental features. This is due to the fact that part of Józefów is located in the Mazowiecki Landscape Park. In addition, the town also includes the specific microclimate of Urzecze, stretching along the rivers Vistula and Pilica. Finally, there are three nature reserves in the city, the Świderskie Islands, the Zawadowskie Islands, and the River Świder, one of the cleanest rivers in Poland. For these reasons, the town is over $50 \%$ forested. The buildings are situated among pines, and the buildings cannot be higher than the height of the tree branches. Thus, the forest character of the buildings has been preserved (Skrzyniar, 1987; Barbachowska, 2013).

The Environmental Protection Programme for the town of Józefów for the years 2021 to 2024, with the perspective for the years 2025 to 2028, is the basis for the environmental protection policy of the municipality (Załącznik nr 1 do uchwały nr 212/VIII/2020 Rady Miasta Józefowa of 29 July 2020). It is quite a long document, of about 130 pages. The main part of this programme is environmental assessment in terms of climate protection and air quality, noise pollution, electromagnetic field, water management, water and sewage management, geological resources, soil, waste management, natural resources and activities aimed at counteracting the risk of major accidents.

Particularly noteworthy is the systematic increase in natural resources since 2014, despite the expansion of the area used for the construction of single-family houses, and the continuous expansion of the municipal infrastructure. The forest area has decreased slightly. Ecological corridors associated with various forms of nature present in the town of Józefów have been preserved.

The adopted objectives in the Environmental Protection Programme for the town of Józefów for the years 2021 to 2024 are consistent with the assumptions in force in strategic documents at national, voivodeship and powiat levels. Moreover, the assumptions adopted in this programme are consistent with the development strategy of the town of Józefów for 2016 to 2025. This includes activities such as the construction of a sewage treatment plant, further expansion of the water supply and sewerage system, development of the area by the River Świder, care for green and forest areas.

The analysis of two normative documents shows that the directions of environmental protection adopted in UN and EU legal acts have been adapted to local needs and requirements. The local authorities assess very carefully the current state of affairs, and develop appropriate instruments of an organisational and financial nature to implement environmental policy, adapting it to local conditions.

\subsection{Local environmental policy in the municipality of Bitetto}

Bitetto is a town in the south of Italy, in the Apulia region, near Bari. The city has approximately 11,600 inhabitants. It is a typical southern Italian town, built on a densely built Medieval structure (Krajewski, 2011: 213-219). However, the origins of the city date back to the seventh century BC, and are associated with the already-developing Greek culture (Greater Greece). Then, in the third century BC, the town underwent a Romanisation process. In the Middle Ages, the place was the seat of the bishop. Due to its history, the city has numerous monuments, hence it is a local tourist centre (Gelao, 1998).

The boundaries of the municipality of Bitetto are the same as the boundaries of the town. Due to the structure of the town consisting of close buildings, there is not much space for green areas. They are small, located mainly on the outskirts of the town, but unfortunately often neglected these days. Inside the town's buildings, green elements are associated with houses or blocks of apartments. A small park is located in the Franciscan friary. This park is generally open to the public. In total, the size of green areas does not exceed 
$2 \%$ of the municipality's area. Local environmental policy is correlated with national and regional policy (Bagliani, Dansero, 2011: 349; Staderini, 2009: 319).

In 2001, a resolution of the Bitetto Commune Council (No 380/2001) was issued introducing principles of urban development. The subject of this resolution was to transform green areas, in order to protect them. The activities in this area have been linked to all decisions by the municipal authorities. In order to better protect small natural resources, it was decided to establish a local landscape commission. The main task of this commission was to work out principles for the urban development of the town, while maintaining existing elements of nature (Article 1.3). The protection of the existing green areas should be taken into account in the urban development plans of the town. These activities determine the quality of this plan (Article 3.2). For these reasons, the actions of the commune's authorities should consider the principles of sustainable development (Article 6).

In turn, on 18 February 2016, the Bitetto Commune Council adopted resolution No 17/2016, called For the Green Citizen (Per il Verde Cittdino). Pursuant to Article 1 of the resolution, the subject of the document is to define the rules for the use, maintenance and protection of green areas in the town. Subsequently, the purpose of the resolution is to encourage sensitivity to the environment, to improve living conditions for the inhabitants, to develop appropriate methods of action for the benefit of urban greenery, to encourage residents to use urban greenery, and at the same time to increase public awareness of the protection of the natural environment. Naturally, these activities concern parks and municipal gardens. These areas are accessible to all citizens. Hence, they also have an obligation to care for greenery (Article 3).

Care for the maintenance of green public areas is undoubtedly the basic task of the municipality (Article 6). For this purpose, the municipal authorities may, by contract, outsource the performance of specific tasks in this area to other private entities (Article 6). The obligation to care for green spaces also rests with private or legal persons who own such areas (Article 7). These entities cannot allow the degradation of green areas. For these reasons, the felling of trees is only allowed in exceptional cases, after obtaining the consent of the public authorities (Article 12). The act also bans placing advertisements among trees (Article 18). Failure to respect the rules in the resolution is subject to administrative sanctions of an amount up to $€ 500$.

\section{Conclusions}

In the mid-20th century, humankind realised the need to protect the environment for the sake of human beings themselves. A human without an environment cannot survive. Environmental protection is necessary not only for the present generation, but also for future generations. The first international actions in the field of environmental protection were undertaken by the United Nations in the 1950s. The turning point was the Earth Summits, starting with the first one, which took place in 1992 in Rio de Janeiro. During this meeting, the Agenda 21 document was adopted, which became the basis for further activities in the field of environmental protection. The most important feature of this document was the introduction of the principle of sustainable development to all development policies, especially economic development. The UN Environment Programme was created within the framework of the United Nations. Its task is to strengthen environmental protection, by creating global legal regulations and taking other necessary action in this area.

However, it was quickly realised that the protection of the natural environment is in fact global in nature, but in its concrete dimension, it is of a regional nature. Hence, United Nation documents began to focus more and more on the need to adapt global environmental protection policy to the requirements and needs of a particular region. The actions taken by the European Union and its member states are an example of the regionalisation of environmental protection. The regionalisation of environmental protection policy goes even lower in the structure of individual countries, down to the municipality itself. It is there that local authorities have the greatest knowledge and possibilities to act effectively for the protection of the environment.

The examples of two different local policy models were presented, based on the activities undertaken by the Józefów municipality in Poland and the Bitetto municipality in Italy. The first of these communes has significant natural resources. Hence, it shapes its policy quite broadly. It includes not only trees, but also 
numerous watercourses, parks and reserves. The commune authorities, referring to the environmental protection standards developed in international law, adapt them to the local needs and possibilities. In an Italian commune, natural resources are extremely meagre. This is due to the historical and urban conditions. Hence, environmental protection policy is limited mainly to the preservation of the trees and small green areas. In order to protect these scarce natural resources, relatively high administrative sanctions have been introduced for their destruction.

These two examples show clearly that global approaches must be translated to the regional and local situation. The two above-mentioned municipalities, which have been cooperating with each other for many years, have very different situations regarding environmental conditions. Therefore, each of them must implement the main components of global or national environmental policy in a different way. Only then will the policy bring positive results and satisfy the needs of local communities in the proper way. An analysis of the provisions and regulations of international law, and the views of the doctrine and the policy of international organisations or individual countries, including Poland and Italy, allows us to conclude that there is a common awareness of the need to undertake legislative, political and educational activities in order to protect the environment. The natural environment has become a common good, and as such is a value in itself. Environmental protection policy is based on the principle of sustainable development.

Another conclusion which emerges from this study is that the effectiveness of environmental protection policy depends on its implementation at the regional or local level. Each region has its own specific conditions, resulting from the natural resources and economic opportunities. There is no doubt that environmental protection requires significant financial outlay, and this determines the scope of activities aimed at environmental protection. A comparative analysis of two local environmental policies, the city of Józefów in Poland and the city of Bitetto in the south of Italy, confirms the validity of the regionalisation of environmental policy. The city of Józefów is very rich in environmental resources. For this reason, the environmental protection policy is very extensive. Significant financial resources are involved in its implementation. The city of Bitetto has very limited natural resources, which means that the financial resources involved are relatively small.

The final conclusion of the study is that adapting the environmental protection policy to regional or local needs is necessary for the effectiveness of global environmental protection policy. The effect of this study is to demonstrate the correctness of the idea that the application of principles of environmental protection developed in international law must be done considering local needs and conditions, primarily at the commune level. Therefore, each region and each local community should analyse the global principles, and then they should translate and implement them to their own conditions and needs. Environmental policy must consider global and national trends, but it must be shaped at a local level. Only then can we see proper results in the area of the protection of the environment.

\section{References}

Antczak, A. (2010). Projektowanie strategii bezpieczeństwa Unii Europejskiej. Józefów.

Alexandrowicz, Z. (1994). Nowa ustawa o ochronie przyrody i jej znaczenie dla zachowania elementow abiotycznych. Przegląd Geologiczny, 42.03, s. 164-165.

Bagliani, M., Dansero, E. (2011). Politiche per l'ambiente dalla natura al territorio. Torino.

Barbachowska, B. (2013). Uwarunkowania społeczno-gospodarczego rozwoju Powiatu Otwockiego. Józefów.

Brugman, J. (2014). Agenda 21 and the Role of Local Government. W: F. Dodds (ed.). Earth Summit 2002: a new deal, s. 40-48. New York.

Ciechanowicz-Maclean, J. (2009). Prawo i polityka ochrony środowiska. Warszawa.

Ciekanowski, Z., Ulijasz, B. (2015). Gospodarka regionalna. Podręcznik akademicki. Warszawa.

Duczkowska-Kądziel, A., Duda. J. (2014). Odpady komunalne i przemysłowe alternatywnymi surowcami i paliwami w procesie produkcji cementu. Prace Instytutu Ceramiki i Materiatów Budowlanych, Vol. 7, s. 172-187.

Gelao, C. (1998). La Cattedrale di Bitetto: le addizioni settecentesche. Bari.

Ignatowski, G. (2013). Oenzetowskie Szczyty Ziemi a kwestia edukacji ekologicznej. Pedagogika Rodziny, Vol. 3.1, s. 93-109.

Il Beato Giacomo e il suo santuario, tavole e schedario del corredo artistico. (1987). Vol. 3. Bari. 
Ivanova, M. (2020). Coloring the UN Environmental: The Catalytic Role of the UN Environment Programme. Global Governance: A Review of Multilateralism and International Organizations, Vol. 26(2), s. 307-324.

Johnson, S. P. (1994). The earth summit: The United Nations conference on environment and development (UNCED). Verfassung und Recht in Übersee, Vol. 28(1), s. 134-135.

Kenig-Witkowska, M. M. (2012). Prawo środowiska Unii Europejskiej. Warszawa.

Krajewski, P. (2011). Urbanizacja i jakość życia. W poszukiwaniu miasta na miare człowieka. In B. Sitek, R. Trzaskalik (eds.). Zarządzanie informacja i energia w systemie bezpieczeństwa Unii Europejskiej. Józefów, s. 213-219.

Olejarczyk, E. (2016). Zasada zrównoważonego rozwoju w systemie prawa polskiego: wybrane zagadnienia. Przegląd Prawa Ochrony Środowiska, Vol. 2, s. 119-140.

Peña Rodriguez, C. F. (2020). Harmonization of EU Contract Law adopted on the basis of Article 114 TFEU. Master Thesis. Lund.

Rakoczy, B. (2009). Prawo ochrony przyrody. Warszawa.

Selman, P. (1998). Local Agenda 21: substance or spin? Journal of environmental planning and management, Vol. 41(5), s. 533-553.

Sitarz, D. (1993). Agenda 21: The earth summit strategy to save our planet. Nova Publishing Co.

Sitek M. (2014). Prawne i instytucjonalne podstawy modelu zrównoważonej konsumpcji w optyce 7. programu działania UE na rzecz ochrony środowiska do roku 2020. Journal of Modern Science, s. 231-247.

Skrzyniarz, I. (1987). 25 lat Józefowa: album. Józefów.

Staderini, F. (2009). Diritto degli enti locali. Padova.

The Internet sources:

Environmental Rule of Law, in: https://www.unep.org/explore-topics/environmental-rights-and-governance/what-wedo/promoting-environmental-rule-law-0 [access: 27.03.2021].

Environmental Rule of Law: First Global Report in: https://www.unep.org/resources/assessment/environmental-rulelaw-first-global-report?_ga=2.126676045.1980575454.1616658395-424029573.1616658395 [access: 27.03.2021].

The structure UN Environmetal Programme in: https://wedocs.unep.org/bitstream/handle/20.500.11822/35352/UNEPOrg.pdf [access: 27.03.2021].

\title{
PASAULINES APLINKOS POLITIKOS IGYVENDINIMO, ATSIŽVELGIANT I VIETOS BENDRUOMENÉS POREIKIUS IR ESAMAS SĄLYGAS, BŪTINYBË. LYGINAMASIS TYRIMAS
}

\author{
Magdalena Sitek, Bronisław Sitek
}

Alcide de Gasperi euroregioninès ekonomikos universitetas Juzefuve, Socialinių ir humanitarinių mokslų universitetas Varšuvoje (Lenkija)

\section{Santrauka}

XX amžiaus viduryje žmonija suprato būtinybę saugoti aplinką paties žmogaus labui. Žmogus be aplinkos išgyventi negali. Saugoti aplinką būtina ne tik dèl dabartinès, bet ir dèl ateities kartų. Aplinka tapo savo pačios vertybe. Gamtos aplinkos apsauga - globalus dalykas. Ji užtikrinama rengiant susitikimus ir atitinkamus dokumentus, globojant Jungtinèms Tautoms. Būtent ten nustatomi pagrindiniai globalūs uždaviniai. Jungtinių Tautų veikla paremta darnaus vystymosi principu, kuris šiandien taikomas visų tipų politikai ir skatina savoje veikloje atsižvelgti ị būtinybę saugoti gamtinę aplinką. 
Vis dèlto pasaulinės aplinkos politikos veiksmingumas priklauso nuo jos igyvendinimo regione. Taigi Jungtinių Tautų dokumentuose vis labiau pabrèžiamas poreikis pasaulinę aplinkos apsaugos politiką pritaikyti konkretiems regiono reikalavimams ir poreikiams. Europos Sajungos ir jos valstybių narių veiksmai yra aplinkos apsaugos regioniškumo pavyzdys. Aplinkos apsaugos politikos regionalizmas siekia žemesni lygmenị - valstybes ir visų pirma savivaldybes. Būtent vietos valdžios institucijos turi daugiausia informacijos, taigi ir veiksmingų aplinkos apsaugos veiksmų galimybę.

Straipsnyje pateikti du skirtingi vietos politikos pavyzdžiai, pagrịsti dviejų savivaldybių iš Lenkijos ir Italijos veiksmais: Juzefuvas (lenk. Komuna Józefów) Lenkijoje ir Biteto (it. Comune di Bitetto) Italijoje. Tai panašaus dydžio miestai, skiriasi tik jų istorinès, miesto ir gamtinès sąlygos. Juzefuvas turi gamtos išteklių, įskaitant miškus, vandens kelius, gyvūnų ir paukščių buveines. Jo aplinkos politika yra visa apimanti: tai ne tik medžių medynas, bet ir daugybe vandens telkinių, parkų, draustinių. Savivaldybių institucijos remiasi tarptautinès teisès nustatytais aplinkos apsaugos standartais. Vietos valdžios institucijų parengtų dokumentų analizè atskleidè, kad visuotiniai aplinkos apsaugos politikos reikalavimai ịgyvendinami atsižvelgiant ị vietos poreikius ir galimybes. Tuo tarpu Italijos Biteto miesto gamtos ištekliai menki: daugiausia žaliosios erdvès (pievos) miesto pakraštyje arba nedidelès vejos ir pavieniai medžiai tankiai užstatytame mieste. Tai lèmè istorinès ir gamtinès miesto sąlygos. Taigi aplinkos apsaugos politika čia apsiriboja medžiu ir nedideliu žaliujų plotų priežiūra. Siekiant apsaugoti šiuos negausius gamtos išteklius, už jų sunaikinimą įvestos gana didelès administracinès sankcijos.

Tyrimo tikslas - parodyti, ar teisingai taikomi tarptautinèje teisejje numatyti aplinkos apsaugos principai, atsižvelgiant į vietos poreikius ir sąlygas, visų pirma komunų lygiu.

PAGRINDINIAI ŽODŽIAI: aplinkos apsauga, vietos valdžios uždaviniai, aplinkos naudojimas.

JEL KLASIFIKACIJA: Q 58.

Received: 2021-03-06

Revised: 2021-04-28

Accepted: 2021-05-04 